Article

\title{
Design and Investigation of Optical Properties of $N$-(Rhodamine-B)-Lactam-Ethylenediamine (RhB-EDA) Fluorescent Probe
}

\author{
Eva Soršak ${ }^{1}$, Julija Volmajer Valh ${ }^{1}$, Špela Korent Urek ${ }^{2}$ and Aleksandra Lobnik ${ }^{1,2, *}$ \\ 1 Institute of Engineering Materials and Design, Faculty of Mechanical Engineering, University of Maribor, \\ Smetanova 17, 2000 Maribor, Slovenia; sorsak.eva@gmail.com (E.S.); julija.volmajer@um.si (J.V.V.) \\ 2 Institute for Environmental Protection and Sensors, Beloruska 7, 2000 Maribor, Slovenia; spela@vips.si \\ * Correspondence: aleksandra.lobnik@um.si; Tel.: +386-2-333-5664
}

Received: 9 March 2018; Accepted: 11 April 2018; Published: 14 April 2018

\begin{abstract}
This study presents chemical modification of a Rhodamine B (RhB) sensor probe by ethylenediamine (EDA), and investigation of its spectral as well as sensor properties to the various metals. The synthesised $N$-(Rhodamine-B)-lactam-ethylenediamine (RhB-EDA) fluorescent probe shows interesting optical sensor properties, and high sensitivity and selectivity to $\mathrm{Ag}^{+}$ions among all the tested metal ions $\left(\mathrm{K}^{+}, \mathrm{Mg}^{2+}, \mathrm{Cu}^{2+}, \mathrm{Ni}^{2+}, \mathrm{Fe}^{2+}, \mathrm{Pb}^{2+}, \mathrm{Na}^{+}, \mathrm{Mn}^{2+}, \mathrm{Li}^{+}, \mathrm{Al}^{3+}, \mathrm{Co}^{2+}, \mathrm{Hg}^{2+}, \mathrm{Sr}^{2+}\right.$, $\mathrm{Ca}^{2+}, \mathrm{Ag}^{+}, \mathrm{Cd}^{2+}$ and $\mathrm{Zn}^{2+}$ ), while the well-known Rhodamine B (RhB) fluorescent probe shows much less sensitivity to $\mathrm{Ag}^{+}$ions, but high sensitivity to $\mathrm{Fe}^{2+}$ ions. The novel fluorescent sensor probe RhB-EDA has the capabilities to sense $\mathrm{Ag}^{+}$ions up to $\mu \mathrm{M}$ ranges by using the fluorescence quenching approach. The probe displayed a dynamic response to $\mathrm{Ag}^{+}$in the range of $0.43 \times 10^{-3}-10^{-6} \mathrm{M}$ with a detection limit of $0.1 \mu \mathrm{M}$. The sensing system of an RhB-EDA novel fluorescent probe was optimised according to the spectral properties, effect of $\mathrm{pH}$ and buffer, photostability, incubation time, sensitivity, and selectivity. Since all the spectral and sensing properties were tested in green aqueous media, although many other similar sensor systems rely on organic solvent solutions, the RhB-EDA sensing probe may be a good candidate for measuring $\mathrm{Ag}^{+}$ions in real-life applications.
\end{abstract}

Keywords: rhodamine B; ethylenediamine; chemical modification; fluorescence quenching; optical detection; $\mathrm{Ag}^{+}$ions

\section{Introduction}

Silver is one of the most poisonous ions that can be found throughout the ecosystems. It is believed that the toxicity of silver originates mainly from the ability of silver ion $\left(\mathrm{Ag}^{+}\right)$to bind with various metabolites and sulfhydryl enzymes, leading to the inactivation of enzymes and, consequently, to the resulting health problems [1]. In addition, it is assumed that the $\mathrm{Ag}^{+}$ions implement adverse effects in patients who overuse medication containing silver salts, causing accumulation in liver tissue [2].

People are exposed to silver due to its wide use in industrial products, such as photographic imaging agents and pharmaceutical products, and consumer products, such as toothpastes, soaps, and deodorants as antimicrobial agents. Human activities, such as alkali and metal processing, incineration of coal, water, and soil, therefore, increase the likelihood of exposure of people to such highly toxic metal. The US Environmental Protection Agency (EPA) has defined a Secondary Maximum Contaminant Level (SMCL) in drinking water for this metal at $0.1 \mathrm{mg} \mathrm{L}^{-1}$ [3]. Thus, the development of probes possessing high selectivity for $\mathrm{Ag}^{+}$ions over other commonly coexistent metal ions in various media is of considerable significance for environmental protection and human health [2].

Although traditional techniques have been applied widely to detect $\mathrm{Ag}^{+}$ions in environmental samples, such as gas chromatography and liquid chromatography [4], atomic absorption/emission 
spectroscopy [5], electro thermal atomic absorption spectrometry [6], Inductively Coupled Plasma-Mass Spectrometry (ICP-MS) [7] and Inductively Coupled Plasma-Atomic Emission Spectrometry (ICP-AES) [8], they require expensive and sophisticated instrumentation and/or time-consuming and complicated sample preparation processes [9]. Therefore, they are not well suited for rapid on-site detection of $\mathrm{Ag}^{+}$ions. Many probe-based sensors intended for on-site detection using organic chromophores, small fluorescent organic molecules [10-12], Quantum Dots (QDs) [13,14], conjugated polymers [15], and DNA-zymes [16] have been developed for fluorescent, colorimetric [17-19], and electrochemical detection of $\mathrm{Ag}^{+}$[20,21]. However, some drawbacks still exist, such as poor aqueous solubility $[18,22]$, bad stability, low sensitivity, large physical size, complicated synthesis procedures, high toxicity, and cross-sensitivity toward other metal ions, especially to $\mathrm{Hg}^{2+}$ [22-25].

Herein, a probe based on fluorophore Rhodamine B (RhB) was synthesised [26]. It was previously used as an intermediate in the synthesis of various rhodamine derivates [26-28] and dendrimers [29,30]. However, to the best of our knowledge, its interesting optical properties and sensitivity to $\mathrm{Ag}^{+}$ions were overlooked. The optical properties of RhB-EDA (3) and its sensitivity to $\mathrm{Ag}^{+}$ions are presented in the proposed article. The sensing characteristics of an RhB-EDA probe were tested in green aqueous ( $90 v / v \% \mathrm{H}_{2} \mathrm{O}, 10 v / v \%$ DMSO) media rather than in different water-organic solvent solutions. The results suggest that RhB-EDA shows great potential as a fluorescent probe for the detection of $\mathrm{Ag}^{+}$ ions in aqueous samples because of its simple synthesis and high selectivity toward $\mathrm{Ag}^{+}$ions.

\section{Materials and Methods}

\subsection{Chemicals and Starting Materials}

The Rhodamine $\mathrm{B}$, etilenediamine (EDA), methyl acrylate, methanol, dimethyl sulfoxide (DMSO), $\mathrm{FeSO}_{4} \cdot 7 \mathrm{H}_{2} \mathrm{O}, \mathrm{CuSO}_{4} \cdot 5 \mathrm{H}_{2} \mathrm{O}, \mathrm{PbSO}_{4}, \mathrm{CoCl}_{2} \cdot 6 \mathrm{H}_{2} \mathrm{O}, \mathrm{Sr}\left(\mathrm{NO}_{3}\right)_{2}, \mathrm{CaCl}_{2} \cdot 2 \mathrm{H}_{2} \mathrm{O}, \mathrm{Zn}\left(\mathrm{NO}_{3}\right)_{2}, \mathrm{Ag}_{2} \mathrm{SO}_{4}$, $\mathrm{Hg}\left(\mathrm{NO}_{3}\right)_{2} \cdot \mathrm{H}_{2} \mathrm{O}, \mathrm{CdSO}_{4} \cdot 2.67 \mathrm{H}_{2} \mathrm{O}$ were from Sigma Aldrich (Slovenia). $\mathrm{MgCl}_{2} \cdot 6 \mathrm{H}_{2} \mathrm{O}, \mathrm{NaNO}_{3}$ and $\mathrm{KNO}_{3}$ were provided by Alkaloid Skopje. $\mathrm{NiCl}_{2} \cdot 6 \mathrm{H}_{2} \mathrm{O}, \mathrm{LiCl}, \mathrm{AlCl}_{3} \cdot 6 \mathrm{H}_{2} \mathrm{O}$ and $\mathrm{Mn}\left(\mathrm{CH}_{3} \mathrm{COO}\right)_{2} \cdot 6 \mathrm{H}_{2} \mathrm{O}$ were purchased from Kemika (Slovenia). The $\mathrm{Na}_{2} \mathrm{CO}_{3}$ and $\mathrm{NaHCO}_{2}$ were provided by Riedel-de Haën (Slovenia). All of the reagents were used as received. The solvent used in synthesis was of analytical grade.

\subsection{Synthetic Procedure and Characterisation Data for RhB-EDA}

$\mathrm{RhB}(\mathbf{1})$ (4 g, $8.35 \mathrm{mmol}$ ) was added to an excess of EDA (2). After refluxing for $2 \mathrm{~h}$, the mixture was cooled to room temperature and quenched with water $(100 \mathrm{~mL})$. Then, the mixture was filtered. The crude product thus obtained was dried in a vacuum dryer at RT to give the compound RhB-EDA (3) as an amber white solid ( $3.68 \mathrm{~g}, 92 \%$ yield). m.p. $218-219^{\circ} \mathrm{C}$ in lit $217-219{ }^{\circ} \mathrm{C}$ [28]; ${ }^{1} \mathrm{H}-\mathrm{NMR}$ (DMSO-d $\mathrm{d}_{6}$, $500 \mathrm{MHz}), \delta$ 7.79-7.74 (m, 1H, ArH), 7.52-7.45 (m, 2H, ArH), 7.02-6.97 (m, 1H, ArH), 6.40-6.30 $(m, 6 \mathrm{H}$, ArH), 3.30-3.34 (m, 8H, $\left.\mathrm{NCH}_{2} \mathrm{CH}_{3}\right), 3.00-2.92\left(m, 2 \mathrm{H}, \mathrm{NCH}_{2} \mathrm{CH}_{2} \mathrm{NH}_{2}\right), 2.18(d d, J=8.7,6.5 \mathrm{~Hz}$, $\left.2 \mathrm{H}, \mathrm{NCH}_{2} \mathrm{CH}_{2} \mathrm{NH}_{2}\right), 1.08\left(t, J=7.0 \mathrm{~Hz}, 12 \mathrm{H}, \mathrm{NCH}_{2} \mathrm{CH}_{3}\right)$ (the exchangeable $\mathrm{NH}_{2}$ signal is hidden); ${ }^{13} \mathrm{C}-\mathrm{NMR}\left(125 \mathrm{MHz}, \mathrm{CDCl}_{3}\right) \delta 12.6,40.8,43.9,44.3,64.8,97.6,105.6,108.1,122.7,123.8,127.9,128.7$, 131.2, 132.3, 148.7, 153.2, 153.4, 168.5; IR (ATR, $v, \mathrm{~cm}^{-1}$ ): 669, 703, 764, 783, 812, 867, 923, 969, 1016, $1078,1117,1151,1200,1218,1232,1266,1307,1329,1352,1375,1427,1466,1480,1514,1542,1584,1615$, $1682,2928,2968$.

\subsection{Solutions}

The RhB-EDA stock solution was prepared by dissolving in DMSO to form a $1 \mathrm{mM}$ stock solution. Since RhB-EDA alone is not soluble in water, stock solution was prepared in a small amount of DMSO. RhB and metal salts were dissolved in distilled water to yield $0.1 \mu \mathrm{M}$ and $1 \mathrm{mM}$ stock solutions, respectively. 
The MOPS (3-( $N$-morpholino)propanesulfonic acid) buffer was obtained by dissolving $2.093 \mathrm{~g}$ of 3-morpholinopropanesulfonic acid in approximately $900 \mathrm{~mL}$ of distilled water. Before being filled up to $100 \mathrm{~mL}$, the solution was adjusted to $\mathrm{pH} 7$ using $70 \%$ perchloric acid. To make the tris(hydroxymethyl)aminomethane (TRIS) buffer, we dissolved $2.092 \mathrm{~g}$ of bis-tris base in $900 \mathrm{~mL}$ of distilled water. Before being filled up to $1000 \mathrm{~mL}$, the solution was adjusted to $\mathrm{pH} 7$ using $70 \%$ perchloric acid. The hydroxyethyl-piperazineethane-sulfonic acid (HEPES) buffer was obtained by dissolving $2.380 \mathrm{~g}$ of 3-morpholinopropanesulfonic acid in approximately $900 \mathrm{~mL}$ of distilled water. Before being filled up to $1000 \mathrm{~mL}$, the solution was adjusted to $\mathrm{pH} 7$ using $70 \%$ perchloric acid. A Phosphate Buffer Stock (PBS) solution was prepared by mixing adequate quantities of $0.1 \mathrm{M} \mathrm{KH}_{2} \mathrm{PO}_{4}$ and $0.1 \mathrm{M} \mathrm{NaOH}$ in distilled water.

Working solutions were prepared using distilled water, buffer and RhB-EDA stock solution to obtain a final RhB-EDA concentration of $10^{-4} \mathrm{M}$. The stock solution of RhB-EDA and working solutions with different $\mathrm{pH}$ values were prepared daily. The test samples were incubated for $20 \mathrm{~min}$ at room temperature prior to measurements.

When the sensing behaviour of RhB-EDA toward metal ions was studied, the stock solutions of RhB-EDA were mixed with metal stock solution, buffer and water in a molar ratio 3:3:14:10. The final concentration of RhB-EDA and metal ions were $0.1 \mathrm{mM}$. Solutions were incubated for $20 \mathrm{~min}$ at room temperature prior to measurements.

\subsection{Instrumentation}

${ }^{1} \mathrm{H}$ NMR spectra were recorded with a $500 \mathrm{MHz}$ spectrometer and are reported in ppm using TMS (tetramethylsilane) as an internal standard. ${ }^{13} \mathrm{C}$ NMR spectra were recorded by a $125 \mathrm{MHz}$ spectrometer. The coupling constants $(J)$ are given in Hz. Multiplicities are indicated as follows: $\mathrm{s}$ (singlet), d (doublet), t (triplet), q (quartet), sep (septet) or m (multiplet). The melting point was determined using a microscope hot stage, and was uncorrected.

UV-VIS spectra were recorded on a PerkinElmer Lambda35 UV/VIS spectrophotometer (supplied by Omega d.o.o., Slovenia). The fluorescent data were taken on a PerkinElmer LS 55 luminescence spectrometer equipped with a Xenon discharge lamp. The excitation and emission slits were varied between 5 and $9 \mathrm{~nm}$. ATR FT-IR spectra were recorded on a Perkin Elmer Spectrum GX spectrometer. The ATR accessory (supplied by Specac Ltd., Orpington, UK) contained a diamond crystal. A total of 16 scans for each sample were taken with a resolution of $4 \mathrm{~cm}^{-1}$. All spectra were recorded at $21^{\circ} \mathrm{C}$ over the wavelength interval between 4000 and $650 \mathrm{~cm}^{-1}$. Mass spectra was performed on a Waters Micromass Q-Tof Premier (supplied by Waters Corporation, Vienna, Austria).

\subsection{Fluorescence Quantum Yield}

The procedure for the determination of RhB-EDA quantum yield was carried out as described elsewhere [31]. Rhodamine $G$ was used as the standard. A quantum yield $\left(\Phi_{s}\right)$ of RhB-EDA was estimated from the fluorescence spectra of RhB-EDA according to Equation (1), where the subscripts $\mathrm{s}$ and $\mathrm{r}$ stand for the sample and the reference (rhodamine G6, $\Phi_{r}=0.95$ in ethanol), respectively. $\Phi$ is the quantum yield, $A$ represents the absorbance at the excitation wavelength, $S$ refers to the integrated emission band areas, and $n_{d}$ is the solvent refractive index:

$$
\Phi_{s}=\Phi_{r} \frac{S_{s}}{S_{r}} \frac{A_{r}}{A_{s}} \frac{n_{D s}^{2}}{n_{D r}^{2}}
$$

\section{Results}

\subsection{Design and Synthesis of RhB-EDA}

In the past, several $\mathrm{Ag}^{+}$ions' probes have been synthesised [11,12,15,22,32]. Nevertheless, these syntheses are multistep processes, and the production is expensive, as well as time consuming. 
Moreover, for the synthesis, organic solvents are often used, and synthesised probes are mostly tested in water-organic solutions. The long-term stability of those probes is also questionable [33]. Therefore, we wanted to synthesise a probe for $\mathrm{Ag}^{+}$ions that would be stable, relatively inexpensive, easy to produce and useful in water samples.

RhB-EDA (3) was synthesised by treating RhB (1) with EDA (2), which was followed by precipitation by water. After filtering the crude product and its drying in a vacuum dryer, RhB-EDA (3) was obtained in a 93\% yield (Scheme 1)

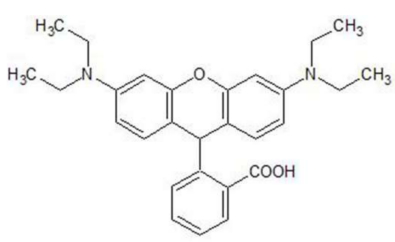

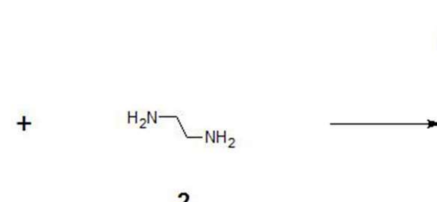

2

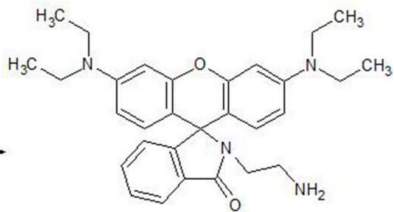

3

Scheme 1. Synthesis of RhB-EDA.

The probe was stored in the dark at Room Temperature (RT) and showed no changes in the structure, as well in the optical properties, after one year.

\subsection{Spectral Properties of Synthesised RhB-EDA Fluorescent Probe}

$\mathrm{RhB}$ is, in the form of green crystals or reddish-violet powder, mixed with water to make a bright pink colour. RhB-EDA is a yellow-white powder that has rather different optical properties. RhB alone shows optical properties with $\lambda_{\text {ex }}$ and $\lambda_{\text {em }}$ at 555/575 nm, while RhB-EDA shows $\lambda_{\text {ex }}$ and $\lambda_{\text {em }}$ at 500/538 nm; RhB-EDA shows negative solvatochromism [34], which is probably due to the intermolecular $\mathrm{H}$ bonds formed between the $\mathrm{NH}_{2}$ groups and $\mathrm{H}_{2} \mathrm{O}$, leading to the higher energy of light needed for the excitation and, consequently, the fluorescence spectra shifted to the lower wavelengths for cca. 40-50 nm.

Relatively small changes in $\mathrm{pH}$ can sometimes affect the intensity and spectral characteristics of fluorescence RhB-EDA radically. In solution at $\mathrm{pH} 7.0$, it is colourless, but the addition of acid is accompanied in the optical properties via change from transparent to pink. Therefore, the effect of $\mathrm{pH}$ on the sensor probe fluorescence characteristic was investigated over a pH range from 4.0 to 7.0 in an MOPS buffer (Figure 1).

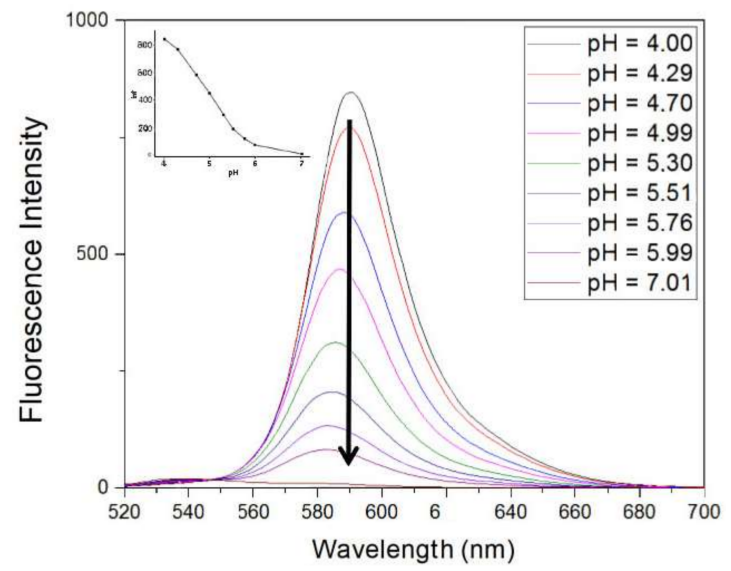

Figure 1. $\mathrm{pH}$ response of RhB-EDA in different $\mathrm{pH}$ from $\mathrm{pH} 4$ to $\mathrm{pH} 7\left(\lambda_{\mathrm{ex}} / \lambda_{\mathrm{em}}=500 \mathrm{~nm} / 590 \mathrm{~nm}\right)$, and the inset shows the titration curve. Figure 1 shows also double emissions at 538 and $590 \mathrm{~nm}$, but emission at 538 is less pronounced due to the high fluorescence intensity at $\mathrm{pH} 4$. Upon increasing the set-up of instrument parameters like detector voltage and ex/em slits, the double emission at $538 \mathrm{~nm}$ is more pronounced (for more information see Section 3.6). 
RhB-EDA is a Rhodamine lactam and, as such, is a part of a group of non-fluorescent and colourless compounds marked by intra-molecular spirolactams, which are poised to form highly fluorescent rhodamine derivatives under appropriate conditions via ring opening of the spirolactam [35-37]. Upon the addition of $\mathrm{H}^{+}$ions (Scheme 2), its structure undergoes a change from the spirolactam to an open ring amide, resulting in a magenta-coloured, highly fluorescent compound $[35,38]$. The fluorescence spectra showed that RhB-EDA fluorescence is the highest at $\mathrm{pH} 4$. The fluorescence intensity of RhB-EDA decreases with $\mathrm{pH}$ increase. $\mathrm{pH}>8$ cannot be used for sensing due to the risk of precipitation of insoluble RhB-EDA. Moreover, at $\mathrm{pH} 4$, quenching of the fluorescence in the presence of different concentrations of $\mathrm{Ag}^{+}$was insignificant. However, on the other hand, at $\mathrm{pH} 7$, the response to the different concentration of the $\mathrm{Ag}^{+}$ions was significant. This is probably due to ring open amide structure at $\mathrm{pH} 4$ and spirolactam form at $\mathrm{pH}$ 7. Therefore, $\mathrm{pH} 7$ was chosen for further experiments.
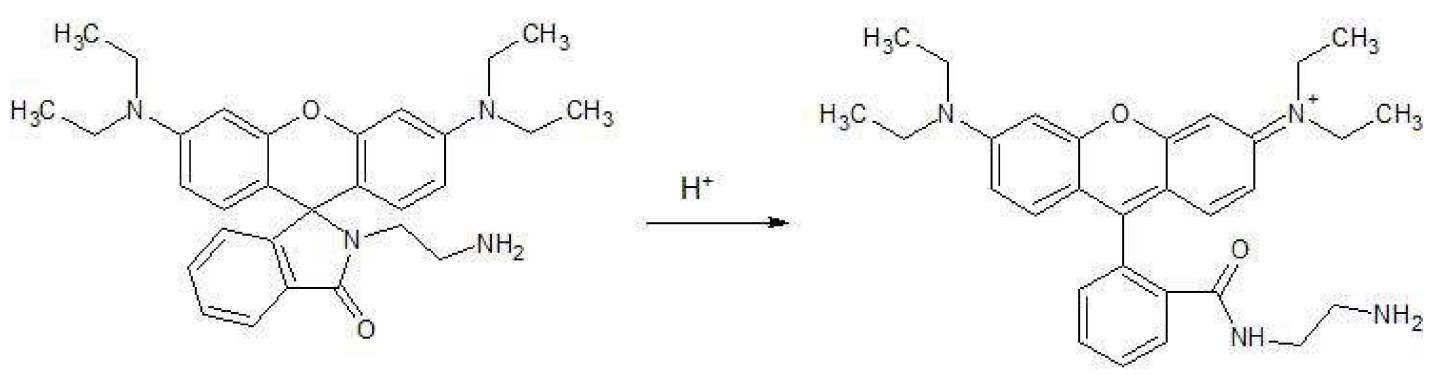

Scheme 2. Transformation of spirolactam form of less fluorescent RhB-EDA to highly fluorescent open ring amide in the presence of $\mathrm{H}^{+}$ion [35].

It is well known that fluorescence probes can be photo unstable [33]. Therefore, we tested the photostability of the RhB-EDA dye in buffer solution. For this reason, the fluorescence intensity of $\mathrm{RhB}-\mathrm{EDA}$ was measured in the absence of $\mathrm{Ag}^{+}$ions; it was recorded every $0.5 \mathrm{~s}$ over an $80 \mathrm{~min}$ period $\left(\lambda_{\text {ex }} / \lambda_{\text {em }}\right.$ was selected at $500 / 538 \mathrm{~nm}$. Slit ex/em $\left.5.0 / 9.0 \mathrm{~nm}\right)$. The fluorescence signal increased by $\Delta \mathrm{I}_{\mathrm{f}}=+9 \%$ after the first $3 \mathrm{~min}$ and then, in an additional $77 \mathrm{~min}$, decreased slowly for an additional $\Delta \mathrm{I}_{\mathrm{f}}=-4 \%$. These effects can also be attributed to the fluctuation of the excitation light source [39].

\subsection{Response of RhB-EDA Fluorescent Probe to Various Metals}

The effect on the fluorescence intensity of an RhB-EDA fluorescent probe in the presence of a range of environmentally and physiologically important metal ions was, furthermore, investigated in a DMSO: $\mathrm{H}_{2} \mathrm{O}(1: 9)$ solvent system buffered with MOPS at $\mathrm{pH} 7.0$ with $\lambda_{\text {ex }}$ and $\lambda_{\text {em }}$ at $500 / 538 \mathrm{~nm}$ (Table 1).

The effect of incubation time was investigated to obtain the best sensitivity. After the addition of $10^{-4} \mathrm{M}$ of $\mathrm{Ag}^{+}$ions, the fluorescence of RhB-EDA started to decrease, and, after $20 \mathrm{~min}$, remained constant. Based on that, a 20 min incubation time was chosen to obtain stable and comparable results on $\mathrm{Ag}^{+}$ions' response (figure not shown).

The selectivity behaviour is obviously one of the most important characteristics of a sensor probe, which reflects the relative response of the probe for primary ion over diverse ions. 
Table 1. Fluorescence signal change of RhB and RhB-EDA to various metals ions at $\mathrm{pH} 7$.

\begin{tabular}{|c|c|c|c|c|c|c|c|c|c|c|c|c|c|c|c|c|c|}
\hline & $\mathrm{K}^{+}$ & $\mathrm{Mg}^{2+}$ & $\mathrm{Cu}^{2+}$ & $\mathrm{Ni}^{2+}$ & $\mathrm{Fe}^{2+}$ & $\mathrm{Pb}^{2+}$ & $\mathrm{Na}^{+}$ & $\mathrm{Mn}^{2+}$ & $\mathrm{Li}^{+}$ & $\mathrm{Al}^{3+}$ & $\mathrm{Co}^{2+}$ & $\mathrm{Hg}^{2+}$ & $\mathrm{Sr}^{2+}$ & $\mathrm{Ca}^{2+}$ & $\mathrm{Ag}^{+}$ & $\mathrm{Cd}^{2+}$ & $\mathrm{Zn}^{2+}$ \\
\hline $\begin{array}{c}\Delta \mathrm{I}_{\mathrm{f}}(\mathrm{RhB}-\mathrm{EDA})(\%) \\
\Delta \mathrm{I}_{\mathrm{f}}(\mathrm{RhB})(\%)\end{array}$ & $\begin{array}{c}0.51 \\
+11.07\end{array}$ & $\begin{array}{l}-0.61 \\
+13.32\end{array}$ & $\begin{array}{r}-7.69 \\
+12.57\end{array}$ & $\begin{array}{l}-1.68 \\
+14.05\end{array}$ & $\begin{array}{l}+0.08 \\
-41.30\end{array}$ & $\begin{array}{l}+4.96 \\
+9.96\end{array}$ & $\begin{array}{r}-0.56 \\
+11.30\end{array}$ & $\begin{array}{l}-3.82 \\
+9.35\end{array}$ & $\begin{array}{l}-2.75 \\
+1.13\end{array}$ & $\begin{array}{l}-5.21 \\
-1.31\end{array}$ & $\begin{array}{l}-2.59 \\
-3.99\end{array}$ & $\begin{array}{l}+11.29 \\
-1.60\end{array}$ & $\begin{array}{l}+1.26 \\
+3.06\end{array}$ & $\begin{array}{l}-0.16 \\
+4.10\end{array}$ & $\begin{array}{l}-75.05 \\
-5.69\end{array}$ & $\begin{array}{c}+0.53 \\
+11.43\end{array}$ & $\begin{array}{l}-2.21 \\
+7.36\end{array}$ \\
\hline
\end{tabular}


The response of the sensor probe $\mathrm{RhB}-\mathrm{EDA}$ to $\mathrm{Ag}^{+}$ions, as well to other environmentally relevant metal ions, was examined, including $\mathrm{K}^{+}, \mathrm{Mg}^{2+}, \mathrm{Cu}^{2+}, \mathrm{Ni}^{2+}, \mathrm{Fe}^{2+}, \mathrm{Pb}^{2+}, \mathrm{Na}^{+}, \mathrm{Mn}^{2+}, \mathrm{Li}^{+}, \mathrm{Al}^{3+}, \mathrm{Co}^{2+}$, $\mathrm{Hg}^{2+}, \mathrm{Sr}^{2+}, \mathrm{Ca}^{2+}, \mathrm{Ag}^{+}, \mathrm{Cd}^{2+}$ and $\mathrm{Zn}^{2+}$. Table 1 and Figure 2 show the signal of the blank sample and change in the fluorescent signal in the presence of different metal ions. Figure 3 also shows that the sensor probe is less sensitive to other metal ions, since the fluorescence signal at $538 \mathrm{~nm}$ was significantly decreased $\left(\Delta \mathrm{I}_{\mathrm{f}}=-75.05 \%\right)$ only in the presence of $\mathrm{Ag}^{+}$ions. The $\mathrm{Ag}^{+}$sensor probes are usually also sensitive to $\mathrm{Hg}^{+}$ions. This is due to the fact that $\mathrm{Ag}^{+}$and $\mathrm{Hg}^{2+}$ are soft ions that display rather similar complex stabilities and, potentially, interfere with each other [40]. In our case, the probe did not behave in such a way. Namely, the fluorescence signal of the probe in the presence of $\mathrm{Hg}^{2+}$ ions was even enhanced by about $\Delta \mathrm{I}_{\mathrm{f}}=+11.29 \%$ (Figure 3). Comparable to the description of $\mathrm{H}^{+}$optical ion behaviour (enhanced fluorescence, Scheme 2), we assume that structure undergoes a change from the spirolactam to an open ring amide and, consequently, carbonyl oxygen and primary amine provide nice binding pockets for $\mathrm{Hg}^{2+}$ (enhanced fluorescence, Scheme 3 ) and also increase the fluorescence intensity $[28,36,37,41,42] \mathrm{Ag}^{+}$ions, on the contrary, show opposite behaviour, and the fluorescence intensity is quenched, probably due to closed spirolactam form and the reduced conjugation of RhB-EDA.

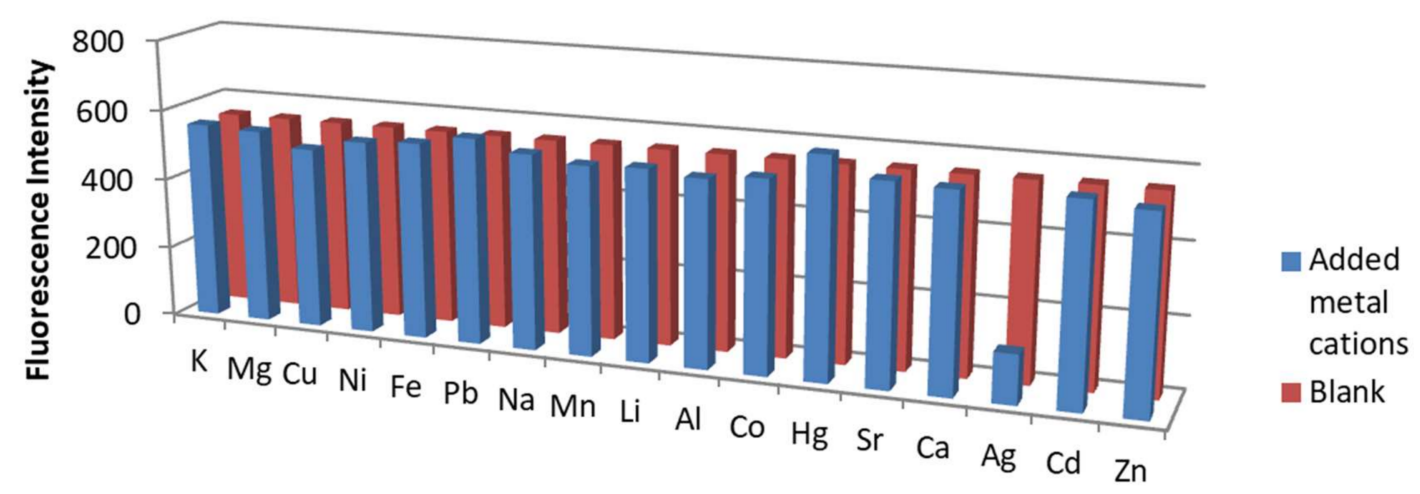

Figure 2. Fluorescence response of $N$-(Rhodamine-B)lactam-ethylenediamine $\left(10^{-4} \mathrm{M}\right)$ at $538 \mathrm{~nm}$ $\left(\lambda_{\mathrm{ex}}=500 \mathrm{~nm}\right)$ as a function of various added metal cations $\left(10^{-3} \mathrm{M}\right)$ in aqueous solution of $100 \mathrm{mM}$ phosphate buffer (pH 7). From left to right: $\mathrm{K}^{+}, \mathrm{Mg}^{2+}, \mathrm{Cu}^{2+}, \mathrm{Ni}^{2+}, \mathrm{Fe}^{2+}, \mathrm{Pb}^{2+}, \mathrm{Na}^{+}, \mathrm{Mn}^{2+}, \mathrm{Li}^{+}, \mathrm{Al}^{3+}$, $\mathrm{Co}^{2+}, \mathrm{Hg}^{2+}, \mathrm{Sr}^{2+}, \mathrm{Ca}^{2+}, \mathrm{Ag}^{+}, \mathrm{Cd}^{2+}, \mathrm{Zn}^{2+} . \lambda_{\mathrm{ex}} / \lambda_{\mathrm{em}}$ was selected at $500 / 538 \mathrm{~nm}$. Slit ex/em 5.0/9.0 nm.

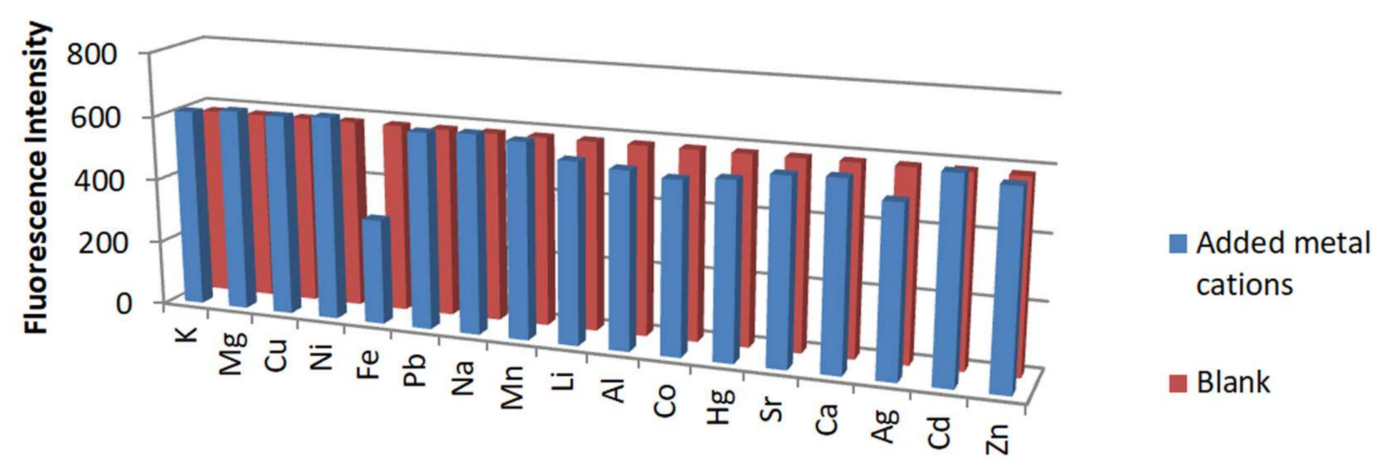

Figure 3. Fluorescence response of Rhodamine $B\left(10^{-7} \mathrm{M}\right)$ at $575 \mathrm{~nm}\left(\lambda_{\mathrm{ex}}=555 \mathrm{~nm}\right)$ as a function of various added metal cations $\left(10^{-3} \mathrm{M}\right.$ ) in aqueous solution of $100 \mathrm{mM}$ phosphate buffer ( $\left.\mathrm{pH} 7\right)$. From left to right: $\mathrm{K}^{+}, \mathrm{Mg}^{2+}, \mathrm{Cu}^{2+}, \mathrm{Ni}^{2+}, \mathrm{Fe}^{2+}, \mathrm{Pb}^{2+}, \mathrm{Na}^{+}, \mathrm{Mn}^{2+}, \mathrm{Li}^{+}, \mathrm{Al}^{3+}, \mathrm{Co}^{2+}, \mathrm{Hg}^{2+}, \mathrm{Sr}^{2+}, \mathrm{Ca}^{2+}, \mathrm{Ag}^{+}$, $\mathrm{Cd}^{2+}, \mathrm{Zn}^{2+} . \lambda_{\mathrm{ex}} / \lambda_{\mathrm{em}}$ was selected at $555 / 575 \mathrm{~nm}$. Slit ex/em 6.0/6.0 nm. 

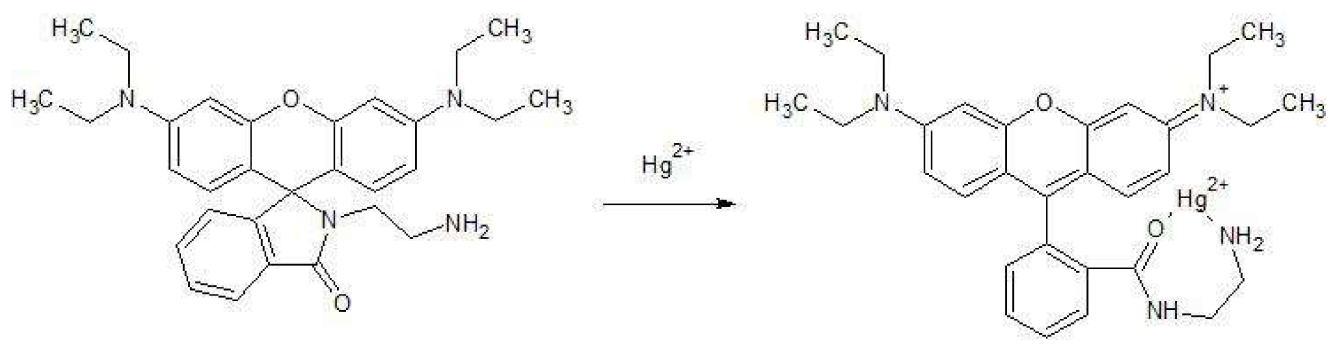

Scheme 3. Transformation of spirolactam form of less fluorescent RhB-EDA to a highly fluorescent open ring amide in the presence of $\mathrm{Hg}^{2+}$ ions [41].

In order to show the impact of the new sensor probe structure RhB-EDA (gained by simple organic modification of $\mathrm{RhB}$ ), on its sensitivity, we also tested the response of RhB to various metal ions. Figure 4 shows the fluorescence response of $\mathrm{RhB}$ itself to various metal ions. The signal change of $\mathrm{RhB}$ in the presence of $\mathrm{Ag}^{+}$ions is rather small $\left(\Delta \mathrm{I}_{\mathrm{f}}=-5.69 \%\right.$; Table 1 and Figure 3). The fluorescence signal change in the case of RhB-EDA in the presence of $\mathrm{Ag}^{+}$ions is much more significant $\left(\Delta \mathrm{I}_{\mathrm{f}}=-75 \%\right.$; Figure 2). The sensor probe RhB showed the biggest sensitivity towards $\mathrm{Fe}^{2+}$ ions $\left(\Delta \mathrm{I}_{\mathrm{f}}=-41.30 \%\right.$; Figure 3), while RhB-EDA shows almost no response to the $\mathrm{Fe}^{2+}$ ions $\left(\Delta \mathrm{I}_{\mathrm{f}}=+0.08 \%\right.$; in the range of measurement error area). The sensitivity of $\mathrm{RhB}$ towards $\mathrm{Fe}^{2+}$ is still smaller than the sensitivity of $\mathrm{RhB}-\mathrm{EDA}$ to $\mathrm{Ag}^{+}$ions. The selectivity test confirms that the RhB and RhB-EDA sensor probes are different, not only in their spectral properties, but also in their sensor behaviour, due to their different structures. This confirms our idea that, with quite easy synthesis, we can obtain a new sensor probe with different sensor characteristics compared to the RhB probe.

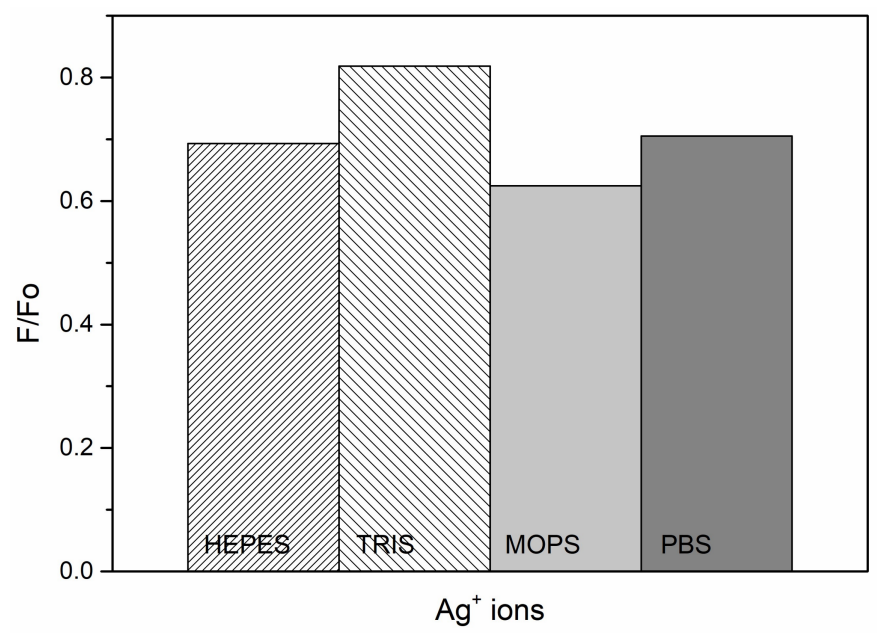

Figure 4. Buffer effect (HEPES, TRIS, MOPS and PBS) on fluorescence intensity of RhB-EDA in the presence of $10^{-4} \mathrm{M} \mathrm{Ag}^{+}$ions. $\lambda_{\mathrm{ex}} / \lambda_{\mathrm{em}}$ was selected at 500/538 nm. Slit ex/em 6.0/6.0 nm.

\subsection{Effect of Buffers}

In several previous studies, the effect of the buffer on the fluorescence intensity has been demonstrated [43,44]. The effect of buffer type on the RhB-EDA fluorescence response to $\mathrm{Ag}^{+}$ion has been tested. Four different buffers (HEPES, TRIS, MOPS and phosphate buffer) have been used (Figure 4). The concentration of RhB-EDA and $\mathrm{Ag}^{+}$ions in the buffers of $\mathrm{pH} 7$ was $10^{-4} \mathrm{M}$ and $10^{-3} \mathrm{M}$, respectively. HEPES and phosphate have no significant effect on the sensitivity of RhB-EDA to $\mathrm{Ag}^{+}$ ions. On the other hand, the TRIS buffer reduced the sensitivity of RhB-EDA towards $\mathrm{Ag}^{+}$ions by $\Delta \mathrm{I}_{\mathrm{f}}=-15 \%$. The highest sensitivity of RhB-EDA has enhanced by $\Delta \mathrm{I}_{\mathrm{f}}=+11 \%$ when the MOPS buffer has been used. The highest signal stability was also observed in the MOPS buffer (Figure 5). Therefore, further studies were carried out in a MOPS buffer after $20 \mathrm{~min}$. 


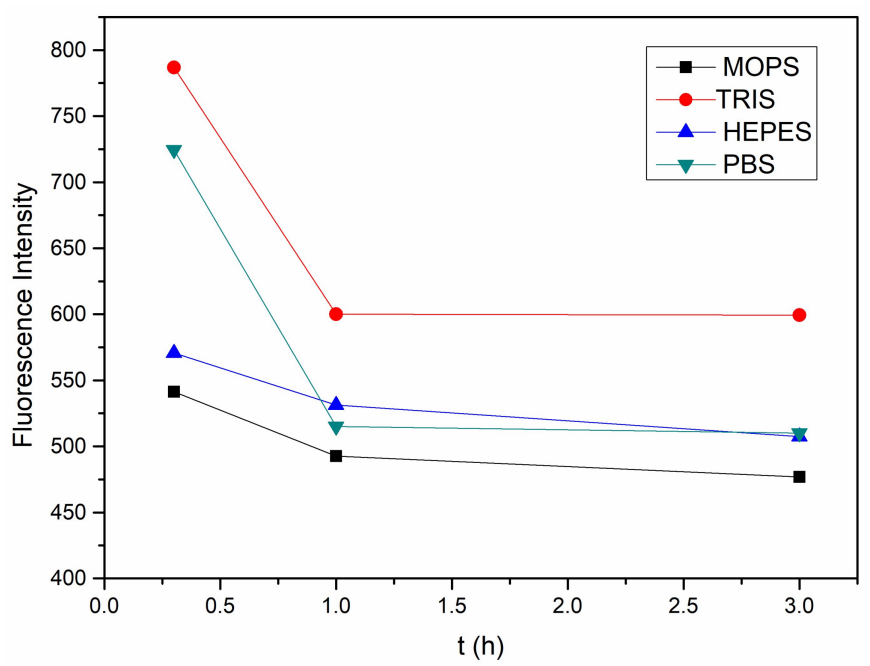

Figure 5. Buffer effect (HEPES, TRIS, MOPS and PBS) on fluorescence intensity of RhB-EDA in the presence of $10^{-4} \mathrm{M} \mathrm{Ag}^{+}$ions depending on time (measurements were taken at time 0 , after 60 min and $3 \mathrm{~h}) . \lambda_{\mathrm{ex}} / \lambda_{\mathrm{em}}$ was selected at $500 / 538 \mathrm{~nm}$. Slit ex/em 6.0/6.0 nm.

\subsection{Effect of Various $\mathrm{pHs}$ of RhB-EDA Fluorescence in the Presence of $\mathrm{Ag}^{+}$Ions}

Many sensor probes that have functional groups, such as $-\mathrm{OH},-\mathrm{CO}_{2} \mathrm{H}$ and $-\mathrm{NH}$, etc., are $\mathrm{pH}$ sensitive $[45,46]$. Therefore, we also tested the $\mathrm{pH}$ effect on RhB-EDA change response in the presence of $\mathrm{Ag}^{+}$ions. Figure 6 shows that the RhB-EDA sensor probe is sensitive to an acidic $\mathrm{pH}$ effect, and silver ions are known to form silver hydroxide at high $\mathrm{pHs}$. Therefore, the $\mathrm{pH}$ effect was tested only in an acid to neutral $\mathrm{pH}$ range $(\mathrm{pH} 4-7)$. The biggest signal change $\left(\Delta \mathrm{I}_{\mathrm{f}}=-700\right)$ of $\operatorname{RhB}-\mathrm{EDA}\left(10^{-4} \mathrm{M}\right)$ fluorescence intensity was obtained in the presence of $\mathrm{Ag}^{+}$ions $\left(10^{-3} \mathrm{M}\right)$ at $\mathrm{pH} 7$ (Figure 6).

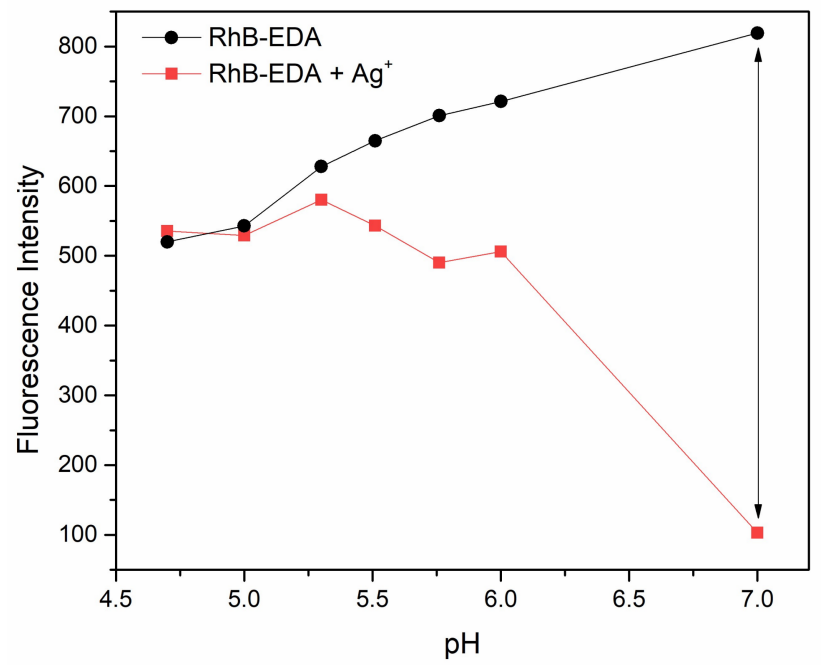

Figure 6. Changes of fluorescence intensity at $538 \mathrm{~nm}\left(\lambda_{\mathrm{ex}}=500 \mathrm{~nm}\right)$ of RhB-EDA $\left(10^{-4} \mathrm{M}\right)$ in aqueous solution of MOPS buffer measured with and without $\mathrm{Ag}^{+}\left(10^{-3} \mathrm{M}\right)$ as a function of $\mathrm{pH}$.

\subsection{Sensitivity of RhB-EDA to $\mathrm{Ag}^{+}$}

Figure 7 shows the fluorescence spectra of the RhB-EDA probe in the absence, and in the presence, of $\mathrm{Ag}^{+}$ions $\left(10^{-4} \mathrm{M}\right)$. In the absence of $\mathrm{Ag}^{+}$ions, RhB-EDA exhibits two emission peaks at $538 \mathrm{~nm}$ and $590 \mathrm{~nm}$. Since the sensitivity of RhB-EDA probe towards $\mathrm{Ag}^{+}$ions was higher at $538 \mathrm{~nm}$ than at $590 \mathrm{~nm}$, the emission peak at $538 \mathrm{~nm}$ was chosen for further investigation. 


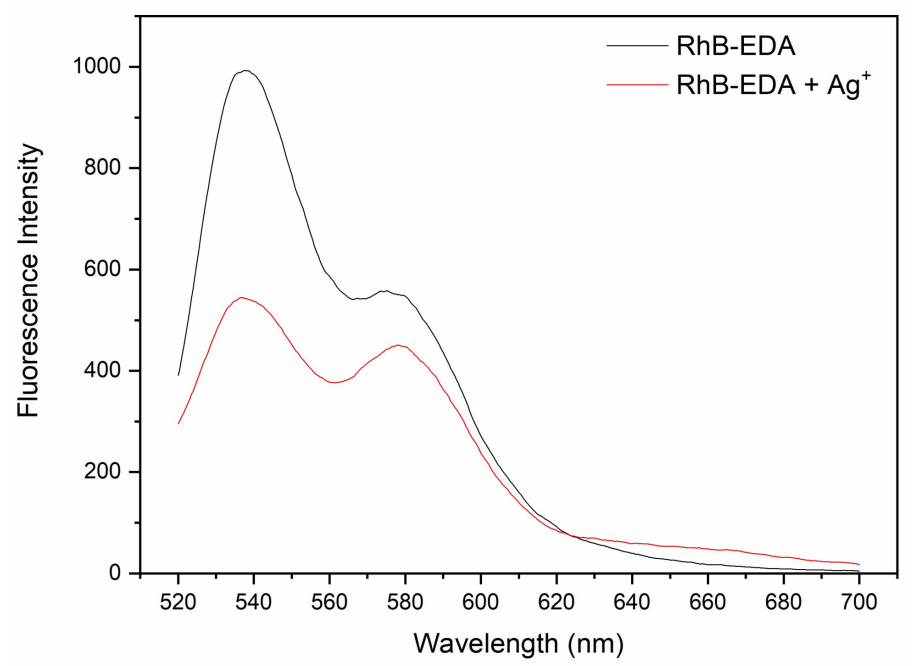

Figure 7. Fluorescence spectra of RhB-EDA alone $\left(10^{-4} \mathrm{M}\right)$ and RhB-EDA $\left(10^{-4} \mathrm{M}\right)$ after addition of $10^{-4} \mathrm{M} \mathrm{Ag}^{+}$ions $\left(\lambda_{\mathrm{ex}} / \lambda_{\mathrm{em}}=500 / 538 \mathrm{~nm}\right)$.

The presence of $\mathrm{Ag}^{+}$ions results in significant fluorescence quenching $\left(\Delta \mathrm{I}_{\mathrm{f}}=-75.05 \%\right)$ after 20 min incubation in an MOPS buffer. For the sensitivity study (Figure 5), different concentrations of $\mathrm{Ag}^{+}$ions in the range from $0.43 \times 10^{-3}$ to $10^{-6} \mathrm{M}$ were investigated in the presence of an RhB-EDA sensor probe. The fluorescence intensity of the RhB-EDA sensor probe decreases with the increase of $\mathrm{Ag}^{+}$concentration. Figure 6 shows the value of $\mathrm{F} / \mathrm{F}_{0}$ plotted against the concentration of $\mathrm{Ag}^{+}$ ions, where $\mathrm{F}_{0}$ and $\mathrm{F}$ are the fluorescence intensity of RhB-EDA, without and with $\mathrm{Ag}^{+}$, respectively. No further decrease in the fluorescence intensity was observed after $\mu \mathrm{M}$ concentration range of $\mathrm{Ag}^{+}$ ions range $\left(>10^{-6} \mathrm{M}\right)$ were used, indicating that the interaction between $\mathrm{RhB}$-EDA and $\mathrm{Ag}^{+}$reached the balance.

Figure 8 shows the presented decrease of fluorescent intensity of the RhB-EDA probe in the presence of various concentrations of $\mathrm{Ag}^{+}$ions. Figure 9 presents a calibration plot of RhB-EDA in the presence of various concentrations of $\mathrm{Ag}^{+}$ions. The limit of detection is $0.1 \mu \mathrm{M}$ of $\mathrm{Ag}^{+}$(LOD, defined as three times the standard deviation of blank).

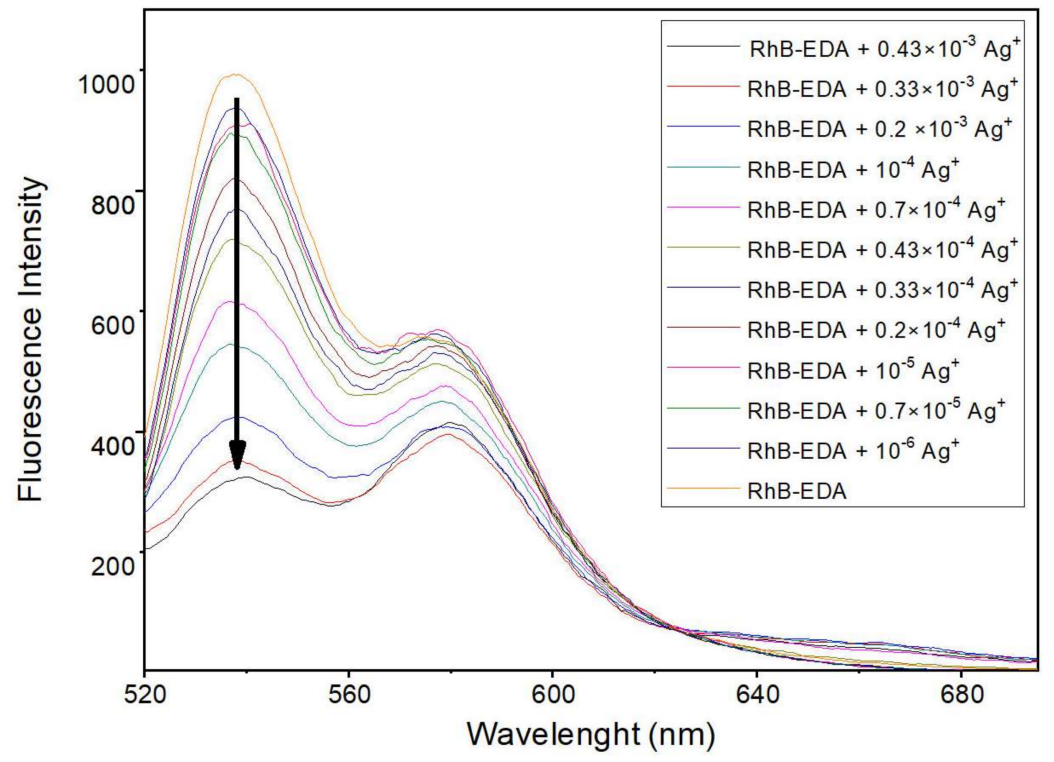

Figure 8. Fluorescence spectra of $100 \mu \mathrm{M}$ RHB-EDA probe in the presence of various concentrations of $\mathrm{Ag}^{+}$ions at $\mathrm{pH} 7$ (DMSO:MOPS: $\left.\mathrm{H}_{2} \mathrm{O}=3: 14: 13\right)\left(\lambda_{\mathrm{ex}} / \lambda_{\mathrm{em}}=500 / 538 \mathrm{~nm}\right)$. 


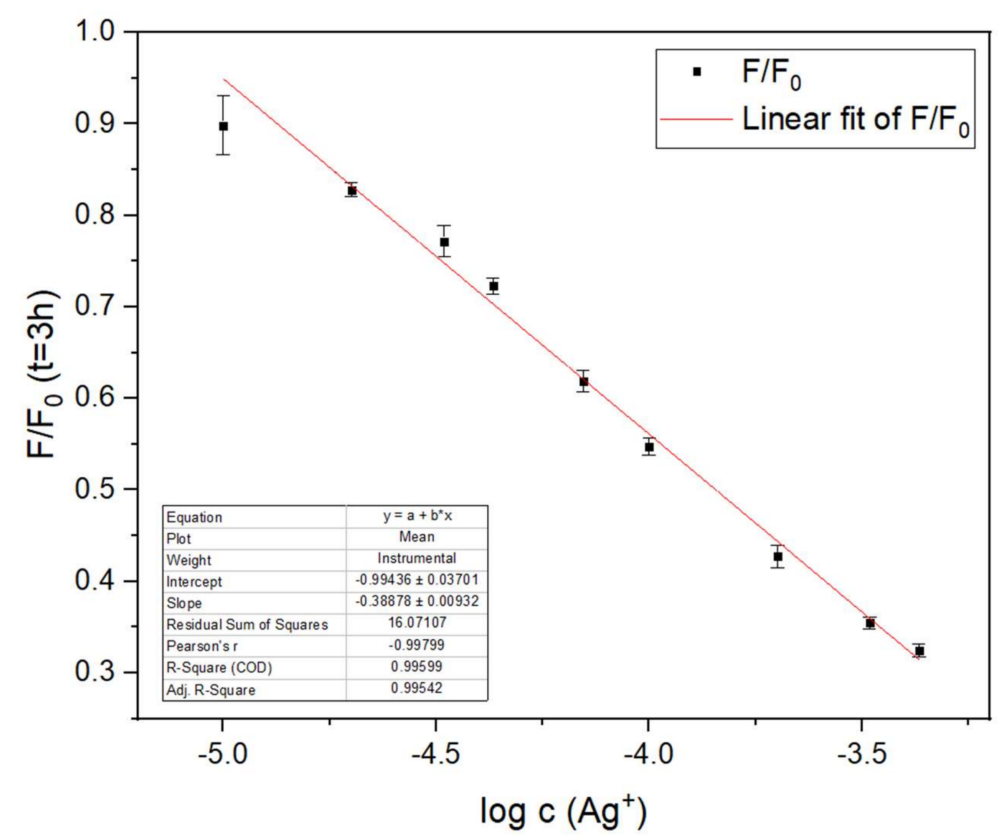

Figure 9. Calibration plot of RhB-EDA in the presence of various $\mathrm{Ag}^{+}$ions concentrations $\left(0.43 \times 10^{-3}\right.$, $0.33 \times 10^{-3}, 0.2 \times 10^{-3}, 10^{-4}, 0.7 \times 10^{-4}, 0.43 \times 10^{-4}, 0.33 \times 10^{-4}, 0.2 \times 10^{-4}, 10^{-5}, 0.7 \times 10^{-5}$, $\left.10^{-6} \mathrm{M}\right)$ in MOPS buffer at $\mathrm{pH} 7\left(\lambda_{\mathrm{ex}} / \lambda_{\mathrm{em}}=500 / 538 \mathrm{~nm}\right)$.

\subsection{Comparison with Developed Probe-Based Sensors Intended for on-Site Detection of $\mathrm{Ag}^{+}$}

In Table 2, the comparison data of developed probes for the on-site determination of the $\mathrm{Ag}^{+}$are listed, along with the synthesized RhB-EDA analyzed within this work.

One can see that the use of fluorescence-based technique is prevailing. $\mathrm{H}_{2} \mathrm{~L} \cdot 2 \mathrm{Br}$ [11] was compared with a lower amount of interference, and determination of $\mathrm{Ag}^{+}$is done in $100 \%$ organic solution; therefore, this fluorescent chemodosimeter is not a candidate for measuring $\mathrm{Ag}^{+}$ions in real-life applications. Since $100 \%$ organic solvent is used for detection of $\mathrm{Ag}^{+}, 2$-Pyridine- $1 \mathrm{H}$-benzo[d]imidazole based conjugated polymer [15] and bis(isatin hydrazonyl) calix[4]arene based dual receptor [18] are also inappropriate probes for real-time application. A phenazine derivate [17] in addition to using a partially organic solvent (DMSO/ $\mathrm{H}_{2} \mathrm{O}(6: 4)$ ), this probe was not tested on $\mathrm{Hg}^{2+}$ as interference, though it is well known that $\mathrm{Ag}^{+}$sensor probes are usually also sensitive to $\mathrm{Hg}^{+}$ions [40]. Apart from phenazine derivate, S-GQDs [13] were also not tested in the presence of $\mathrm{Hg}^{2+}$ ions, so selectivity of this probe is also questionable. No selectivity, due to a similar response to $\mathrm{Ag}^{+}$and $\mathrm{Hg}^{2+}$, showed a Squaraine based probe [22]. $\mathrm{Fe}_{3} \mathrm{O}_{4} @ \mathrm{Au}[21]$ has interference in the presence of a high concentration of $\mathrm{Hg}^{2+}$ ions, and measurement was taken in media with high $\mathrm{pH}(\mathrm{pH}>12)$, which is less suitable for real-time samples. In the case of an FQ-crown [19], all tested ions $\left(\mathrm{K}^{+}, \mathrm{Mg}^{2+}, \mathrm{Cu}^{2+}, \mathrm{Ni}^{2+}, \mathrm{Fe}^{3+}\right.$, $\mathrm{Pb}^{2+}, \mathrm{Mn}^{2+}, \mathrm{Co}^{2+}, \mathrm{Hg}^{2+}, \mathrm{Cr}^{3+}, \mathrm{Ca}^{2+}, \mathrm{Cd}^{2+}, \mathrm{Zn}^{2+}$ ) slightly interfere with $\mathrm{Ag}^{+}$. Fluorescent $\mathrm{N}$ doped C-dots [14] have quite a similar response to $\mathrm{Hg}^{2+}$ and $\mathrm{Ag}^{+}$, and the impact of different $\mathrm{pH}$ is not known. Another Rhodamine B derivate [12] was used as a probe-based sensor with good sensitivity to $\mathrm{Ag}^{+}$but may not be reversible. A change in color results upon binding $\mathrm{Ag}^{+}$to the iodide in an elimination reaction.

The detection limit of the proposed RhB-EDA probe is lower compared to probes with similar detection mechanisms $[12,17,22]$. The sensors' probes $[13,14,16]$ that use nanoparticles have lower limit of detection than the proposed RhB-EDA probe.

Compared to current probes for determination of $\mathrm{Ag}^{+}$, the RhB-EDA can be synthesized easily without any complicated processes and used for determination of $\mathrm{Ag}^{+}$in aqueous media. Moreover, as the probe displays a selective fluorescence response at wavelength $538 \mathrm{~nm}$, it is more suitable for practical determination due to compatibility with cheap light sources. 
Table 2. Comparison data of developed probe-based sensors intended for on-site detection of $\mathrm{Ag}^{+}$.

\begin{tabular}{|c|c|c|c|c|c|}
\hline Indicator & Tested Interference & Solutions & LOD & Remark & [Ref.] \\
\hline RhB-EDA & $\begin{array}{c}\mathrm{K}^{+}, \mathrm{Mg}^{2+}, \mathrm{Cu}^{2+}, \mathrm{Ni}^{2+}, \mathrm{Fe}^{2+}, \mathrm{Pb}^{2+}, \mathrm{Na}^{+}, \mathrm{Mn}^{2+}, \mathrm{Li}^{+}, \\
\mathrm{Al}^{3+}, \mathrm{Co}^{2+}, \mathrm{Hg}^{2+}, \mathrm{Sr}^{2+}, \mathrm{Ca}^{2+}, \mathrm{Cd}^{2+}, \mathrm{Zn}^{2+}\end{array}$ & & $0.1 \mu \mathrm{M}$ & & our work \\
\hline $\mathrm{H}_{2} \mathrm{~L} \cdot 2 \mathrm{Br}$ & $\begin{array}{l}\mathrm{Cu}^{2+}, \mathrm{Ni}^{2+}, \mathrm{Fe}^{2+}, \mathrm{Pb}^{2+}, \mathrm{Mn}^{2+}, \\
\mathrm{Co}^{2+}, \mathrm{Hg}^{2+}, \mathrm{Cr}^{++}, \mathrm{Zn}^{2+}\end{array}$ & $\begin{array}{c}\text { Acetonitrile/dichloromethane } \\
\text { (1:1) }\end{array}$ & Not given & $\begin{array}{l}\text { F, Low number of tested interference, } 100 \% \\
\text { organic solution }\end{array}$ & [11] \\
\hline Rhodamine B derivate & $\begin{array}{l}\mathrm{Mg}^{2+}, \mathrm{Cu}^{+}, \mathrm{Cu}^{2+}, \mathrm{Ba}^{2+}, \mathrm{Ni}^{2+}, \mathrm{Fe}^{3+}, \mathrm{Pd}^{2+}, \mathrm{Mn}^{2+}, \\
\mathrm{Co}^{2+}, \mathrm{Hg}^{2+}, \mathrm{Hg}^{+}, \mathrm{Ca}^{2+}, \mathrm{Cd}^{2+}, \mathrm{Cr}^{3+}, \mathrm{Zn}^{2+}\end{array}$ & $20 \%$ ethanolic water & $0.144 \mu \mathrm{M}$ & $\begin{array}{l}\text { F, Rhodamine B derivate, less number of tested } \\
\text { interference, it is not reversible }\end{array}$ & [12] \\
\hline S-GQDs & $\begin{array}{c}\mathrm{K}^{+}, \mathrm{Mg}^{2+}, \mathrm{Cu}^{2+}, \mathrm{Ni}^{2+}, \mathrm{Fe}^{2+}, \mathrm{Pb}^{2+}, \mathrm{Na}^{+}, \mathrm{Al}^{3+}, \mathrm{Co}^{2+}, \\
\mathrm{Ca}^{2+}, \mathrm{Cd}^{2+} \mathrm{Zn}^{2+}\end{array}$ & HEPES buffer solution & $30 \mathrm{nM}$ & $\begin{array}{l}\text { F, Not tested on } \mathrm{Hg}^{+} \text {as well know interference } \\
\text { for } \mathrm{Ag}^{+} \text {ot tested }\end{array}$ & [13] \\
\hline NCDs & $\begin{array}{c}\mathrm{Mg}^{2+}, \mathrm{Cu}^{2+}, \mathrm{Ni}^{2+}, \mathrm{Fe}^{2+}, \mathrm{Fe}^{3+}, \mathrm{Ba}^{2+}, \mathrm{Mn}^{2+}, \mathrm{Pb}^{2+}, \\
\mathrm{Cr}^{6+}, \mathrm{Cr}^{3+}, \mathrm{Hg}^{2+}, \mathrm{Ca}^{2+}, \mathrm{Cd}^{2+}, \mathrm{Zn}^{2+}\end{array}$ & $100 \%$ water solution & $1 \mathrm{nM}$ & $\begin{array}{c}\text { F, No selectivity: same response to } \mathrm{Ag}^{+} \text {and } \\
\mathrm{Hg}^{2+} \text {, not tested to different } \mathrm{pH}\end{array}$ & [14] \\
\hline $\begin{array}{c}\text { Polymer (ethyl } \\
\text { 2-(2-(pyridin-2-yl)-1H-benzo } \\
{[d] \text { imidazol-1-yl) acetate units) }}\end{array}$ & $\begin{array}{l}\mathrm{Ba}^{2+}, \mathrm{Mg}^{2+}, \mathrm{Cr}^{3+}, \mathrm{Ni}^{2+}, \mathrm{Fe}^{2+}, \mathrm{Na}^{+}, \mathrm{Mn}^{2+}, \mathrm{Li}^{+}, \\
\mathrm{Al}^{3+}, \mathrm{Co}^{3+}, \mathrm{Hg}^{2+}, \mathrm{Sn}^{2+}, \mathrm{Ca}^{2+}, \mathrm{Cd}^{2+}, \mathrm{Zn}^{2+}\end{array}$ & THF solution & Not given & F, $100 \%$ organic solution & [15] \\
\hline $\mathrm{MnO}_{2}$ nanosheets + ligand-DNA & $\begin{array}{c}\mathrm{Ba}^{2+}, \mathrm{Mg}^{2+}, \mathrm{Fe}^{3+}, \mathrm{Mn}^{2+}, \mathrm{Li}^{+}, \mathrm{Al}^{3+}, \mathrm{Cu}^{2+}, \mathrm{Hg}^{2+}, \\
\mathrm{Ca}^{2+}, \mathrm{Cd}^{2+}, \mathrm{Zn}^{2+}\end{array}$ & $\begin{array}{l}\text { Ammonium acetate-buffered } \\
\text { saline solution }\end{array}$ & $9.1 \mathrm{nM}$ & & [16] \\
\hline Phenazine derivate & $\begin{array}{c}\mathrm{Fe}^{3+}, \mathrm{Hg}^{2+}, \mathrm{Ca}^{2+}, \mathrm{Cu}^{2+}, \mathrm{Co}^{2+}, \mathrm{Ni}^{2+}, \mathrm{Cd}^{2+}, \mathrm{Pb}^{2+} \\
\mathrm{Zn}^{2+}, \mathrm{Cr}^{3+}, \mathrm{Mg}^{2+}\end{array}$ & $\begin{array}{c}\text { DMSO/ } / \mathrm{H}_{2} \mathrm{O}(6: 4) \\
\text { HEPES buffer }(\mathrm{pH}=7.2)\end{array}$ & $0.325 \mu \mathrm{M}$ & A, F, Long and complicated synthesis & [17] \\
\hline $\begin{array}{l}\text { bis(isatin hydrazonyl) calix[4]arene } \\
\text { based dual receptors }\end{array}$ & $\mathrm{Cu}^{2+}, \mathrm{Ni}^{2+}, \mathrm{Fe}^{2+}, \mathrm{Mn}^{2+}, \mathrm{Co}^{2+}, \mathrm{Hg}^{2+}, \mathrm{Cd}^{2+}, \mathrm{Zn}^{2+}$ & THF solution & $3.98 \mu \mathrm{M}$ & A, $100 \%$ organic solution & [18] \\
\hline FQ-crown & $\begin{array}{c}\mathrm{K}^{+}, \mathrm{Mg}^{2+}, \mathrm{Cu}^{2+}, \mathrm{Ni}^{2+}, \mathrm{Fe}^{3+}, \mathrm{Pb}^{2+}, \mathrm{Mn}^{2+}, \mathrm{Co}^{2+}, \\
\mathrm{Hg}^{2+}, \mathrm{Cr}^{3+}, \mathrm{Ca}^{2+}, \mathrm{Cd}^{2+}, \mathrm{Zn}^{2+}\end{array}$ & EtOH & Not given & F, All tested interference slightly interfere & [19] \\
\hline DNA probe & $\mathrm{Cu}^{2+}, \mathrm{Hg}^{2+}, \mathrm{Ca}^{2+}, \mathrm{Al}^{3+}, \mathrm{Na}^{+}, \mathrm{K}^{+}, \mathrm{Pb}^{2+}, \mathrm{Cd}^{2+}, \mathrm{Zn}^{2+}$ & $\begin{array}{l}10 \mathrm{mM} \text { Tris-HCl with } 50 \mathrm{mM} \\
{\left[\mathrm{Ru}\left(\mathrm{NH}_{3}\right)_{6}\right]^{3+}(\mathrm{pH} 7.4)}\end{array}$ & $0.1 \mathrm{nM}$ & E, complicated preparation of probe & [20] \\
\hline $\mathrm{Fe}_{3} \mathrm{O}_{4} @ \mathrm{Au}$ & $\begin{array}{r}\mathrm{Mg}^{2+}, \mathrm{Cu}^{2+}, \mathrm{Fe}^{3+}, \mathrm{Co}^{2+}, \mathrm{Hg}^{2+}, \mathrm{Ca}^{2+}, \mathrm{Al}^{3+}, \mathrm{Pb}^{2+}, \\
\mathrm{Cd}^{2+}, \mathrm{Zn}^{2+}\end{array}$ & Water, $\mathrm{pH}>12$ & $59 \mathrm{nM}$ & $\begin{array}{l}\mathrm{E} \text {, interference with high concentration of } \mathrm{Hg}^{2+} \text {, } \\
\text { measuring in media with high } \mathrm{pH}\end{array}$ & [21] \\
\hline Squaraine dye & $\begin{array}{c}\mathrm{K}^{+}, \mathrm{Mg}^{2+}, \mathrm{Cu}^{2+}, \mathrm{Ni}^{2+}, \mathrm{Fe}^{3+}, \mathrm{Pb}^{2+}, \mathrm{Na}^{+}, \mathrm{Mn}^{2+}, \mathrm{Li}^{+}, \\
\mathrm{Al}^{3+}, \mathrm{Co}^{2+}, \mathrm{Hg}^{2+}, \mathrm{Ca}^{2+}, \mathrm{Cd}^{2+}, \mathrm{Ba}^{2+}, \mathrm{Zn}^{2+}\end{array}$ & $\mathrm{EtOH} / \mathrm{H}_{2} 0(50: 50, v / v)$ & $40 \mu \mathrm{M}$ & $\begin{array}{l}\text { F, Long and complicated synthesis, } \mathrm{No} \\
\text { selectivity: similar response to } \mathrm{Ag}^{+} \text {and } \mathrm{Hg}^{2+}\end{array}$ & [22] \\
\hline
\end{tabular}

E—electrochemical-based assay; A—absorbance-based assay, F-fluorescence-based assay. 


\section{Conclusions}

We can conclude that we have synthesised and optimised a fluorescent sensor probe successfully, based on organic modification of a well-known RhB fluorescent probe. As expected, the new probe showed significant changes in its behaviour as an optical sensor probe. By this modification, we obtained a highly sensitive and selective probe for sensing $\mathrm{Ag}^{+}$ions. The $\mathrm{Ag}^{+}$sensor probes are usually also sensitive to $\mathrm{Hg}^{2+}$ ions, but RhB-EDA shows only selective optical sensitivities towards $\mathrm{Ag}^{+}$ions. Furthermore, it was found that the probe response is also influenced by the type of buffer. Among all those tested, it was shown that the sensitivity toward $\mathrm{Ag}^{+}$ions is the highest in the MOPS buffer. The linear range for $\mathrm{Ag}^{+}$ions' detection is from $0.43 \times 10^{-3}$ to $10^{-6} \mathrm{M}$ and LOD is $0.1 \mu \mathrm{M}$. Since all sensing characteristics of the RhB-EDA were tested in green aqueous media and not in different organic solvent solutions, this probe may be a good candidate for measuring $\mathrm{Ag}^{+}$ions in real-life applications. We show successfully that simple, fast and inexpensive synthesis can contribute to the novel fluorescent $\mathrm{Ag}^{+}$sensor probe.

Moreover, our next step will be to immobilise this sensor probe in sol-gel thin film and in $\mathrm{SiO}_{2}$ nanoparticles, since, in our previous work, we have shown that this can improve the sensor characteristics. Therefore, the goal of the research was to synthesise a sensor probe for $\mathrm{Ag}^{+}$ion detection that would be stable, relatively inexpensive, easy to produce and useful in green aqueous media.

Acknowledgments: This work was supported financially by grants from the Slovenian Research Agency (ARRS) for Young Researchers (Grant 1000-10-310043 and, partially, Grant P1-0230-0103). The authors are grateful to Marijan Kočevar, Faculty of Chemistry and Chemical Technology, University of Ljubljana, Slovenia for professional support and carrying out NMR spectra and elemental analyses, and to Dušan Žigon, Mass Spectrometry Centre at the Jozef Stefan Institute, Slovenia for carrying out the MS measurements.

Author Contributions: Eva Soršak contributed to the design of the experiments and performed the experiments, analyzed the data and wrote a paper. Julija Volmajer Valh contributed to the design and performance of experiments, data analyses and paper writing. Špela Korent Urek contributed to the design and performance of experiments, data analyses and paper writing. Aleksandra Lobnik contributed to the design of experiments, data analyses and paper writing.

Conflicts of Interest: The authors declare no conflict of interest.

\section{References}

1. Ratte, H.T. Bioaccumulation and toxicity of silver compounds: A review. Environ. Toxicol. Chem. 1999, 18, 89-108. [CrossRef]

2. Lv, Y.; Zhu, L.; Liu, H.; Wu, Y.; Chen, Z.; Fu, H.; Tian, Z. Single-fluorophore-based fluorescent probes enable dual-channel detection of $\mathrm{Ag}^{+}$and $\mathrm{Hg}^{2+}$ with high selectivity and sensitivity. Anal. Chim. Acta 2014, 839, 74-82. [CrossRef] [PubMed]

3. Arulraj, A.D.; Devasenathipathy, R.; Chen, S.-M.; Vasantha, V.S.; Wang, S.-F. Highly selective and sensitive fluorescent chemosensor for femtomolar detection of silver ion in aqueous medium. Sens. Bio-Sens. Res. 2015, 6, 19-24. [CrossRef]

4. Jones, P.; Beere, H.G. Ion chromatography determination of trace silver ions using hydrophilic resins with chemiluminescence detection. Anal. Proc. Incl. Anal. Commun. 1995, 32, 169-171. [CrossRef]

5. Kazemi, E.; Haji Shabani, A.M.; Dadfarnia, S. Synthesis and characterization of a nanomagnetic ion imprinted polymer for selective extraction of silver ions from aqueous samples. Microchim. Acta 2015, 182, 1025-1033. [CrossRef]

6. Ghanei-Motlagh, M.; Fayazi, M.; Taher, M.A.; Jalalinejad, A. Application of magnetic nanocomposite modified with a thiourea based ligand for the preconcentration and trace detection of silver(I) ions by electrothermal atomic absorption spectrometry. Chem. Eng. J. 2016, 290, 53-62. [CrossRef]

7. Ndung'u, K.; Ranville, M.A.; Franks, R.P.; Flegal, A.R. On-line determination of silver in natural waters by inductively-coupled plasma mass spectrometry: Influence of organic matter. Mar. Chem. 2006, 98, 109-120. [CrossRef] 
8. Shamsipur, M.; Reza Hashemi, O.; Salavati-Niasari, M. Selective flotation-separation and inductively coupled plasma-atomic emission spectrometric determination of ultra trace amounts of silver ion using bis(2-mercaptoanil)acetylacetone. Sep. Sci. Technol. 2007, 42, 567-578. [CrossRef]

9. Zhiani, R.; Ghanei-Motlag, M.; Razavipanah, I. Selective voltammetric sensor for nanomolar detection of silver ions using carbon paste electrode modified with novel nanosized Ag(I)-imprinted polymer. J. Mol. Liq. 2016, 219, 554-560. [CrossRef]

10. Kaur, K.; Saini, R.; Kumar, A.; Luxami, V.; Kaur, N.; Singh, P.; Kumar, S. Chemodosimeters: An approach for detection and estimation of biologically and medically relevant metal ions, anions and thiols. Coord. Chem. Rev. 2012, 256, 1992-2028. [CrossRef]

11. Zhang, H.; Xie, L.; Yan, W.; He, C.; Cao, X.; Duan, C. Conformational switching fluorescent chemodosimeter for the selective detection of silver(I) ions. New J. Chem. 2009, 33, 1478-1481. [CrossRef]

12. Chatterjee, A.; Santra, M.; Won, N.; Kim, S.; Kim, J.K.; Kim, S.B.; Ahn, K.H. Selective fluorogenic and chromogenic probe for detection of silver ions and silver nanoparticles in aqueous media. J. Am. Chem. Soc. 2009, 131, 2040-2041. [CrossRef] [PubMed]

13. Bian, S.; Shen, C.; Qian, Y.; Liu, J.; Xi, F.; Dong, X. Facile synthesis of sulfur-doped graphene quantum dots as fluorescent sensing probes for $\mathrm{Ag}^{+}$ions detection. Sens. Actuators B Chem. 2017, 242, 231-237. [CrossRef]

14. Ren, G.; Zhang, Q.; Li, S.; Fu, S.; Chai, F.; Wang, C.; Qu, F. One pot synthesis of highly fluorescent N doped $\mathrm{C}$-dots and used as fluorescent probe detection for $\mathrm{Hg}^{2+}$ and $\mathrm{Ag}^{+}$in aqueous solution. Sens. Actuators $B$ Chem. 2016, 243, 244-253. [CrossRef]

15. Xiang, G.; Wang, L.; Cui, W.; An, X.; Zhou, L.; Li, L.; Cao, D. 2-pyridine-1h-benzo[d]imidazole based conjugated polymers: A selective fluorescent chemosensor for $\mathrm{Ni}^{2+}$ or $\mathrm{Ag}^{+}$depending on the molecular linkage sites. Sens. Actuators B Chem. 2014, 196, 495-503. [CrossRef]

16. Qi, L.; Yan, Z.; Huo, Y.; Hai, X.-M.; Zhang, Z.-Q. $\mathrm{MnO}_{2}$ nanosheet-assisted ligand-DNA interaction-based fluorescence polarization biosensor for the detection of $\mathrm{Ag}^{+}$ions. Biosens. Bioelectron. 2017, 87, 566-571. [CrossRef] [PubMed]

17. Li, W.-T.; Wu, G.-Y.; Qu, W.-J.; Li, Q.; Lou, J.-C.; Lin, Q.; Yao, H.; Zhang, Y.-M.; Wei, T.-B. A colorimetric and reversible fluorescent chemosensor for $\mathrm{Ag}^{+}$in aqueous solution and its application in implication logic gate. Sens. Actuators B Chem. 2017, 239, 671-678. [CrossRef]

18. Chawla, H.M.; Gupta, T. New chromogenic bis(isatin hydrazonyl)calix[4]arenes for dual recognition of fluoride and silver ions. Tetrahedron Lett. 2013, 54, 1794-1797. [CrossRef]

19. Wang, H.-H.; Xue, L.; Qian, Y.-Y.; Jiang, H. Novel ratiometric fluorescent sensor for silver ions. Org. Lett. 2010, 12, 292-295. [CrossRef] [PubMed]

20. Miao, P.; Han, K.; Wang, B.; Luo, G.; Wang, P.; Chen, M.; Tang, Y. Electrochemical detection of aqueous $\mathrm{Ag}^{+}$ based on $\mathrm{Ag}^{+}$-assisted ligation reaction. Sci. Rep. 2015, 5, 9161. [CrossRef] [PubMed]

21. Yang, H.; Liu, X.; Fei, R.; Hu, Y. Sensitive and selective detection of $\mathrm{Ag}^{+}$in aqueous solutions using $\mathrm{Fe}_{3} \mathrm{O}_{4} @ \mathrm{Au}$ nanoparticles as smart electrochemical nanosensors. Talanta 2013, 116, 548-553. [CrossRef] [PubMed]

22. Fan, J.; Chen, C.; Lin, Q.; Fu, N. A fluorescent probe for the dual-channel detection of $\mathrm{Hg}^{2+} / \mathrm{Ag}^{+}$and its $\mathrm{Hg}^{2+}$-based complex for detection of mercapto biomolecules with a tunable measuring range. Sens. Actuators B Chem. 2012, 173, 874-881. [CrossRef]

23. Palanisamy, S.; Thangavelu, K.; Chen, S.-M.; Velusamy, V.; Chang, M.-H.; Chen, T.-W.; Al-Hemaid, F.M.A.; Ali, M.A.; Ramaraj, S.K. Synthesis and characterization of polypyrrole decorated graphene/ $\beta$-cyclodextrin composite for low level electrochemical detection of mercury (II) in water. Sens. Actuators B Chem. 2017, 243, 888-894. [CrossRef]

24. Palanisamy, S.; Madhu, R.; Chen, S.-M.; Ramaraj, S.K. A highly sensitive and selective electrochemical determination of $\mathrm{Hg}$ (II) based on an electrochemically activated graphite modified screen-printed carbon electrode. Anal. Methods 2014, 6, 8368-8373. [CrossRef]

25. Amanulla, B.; Palanisamy, S.; Chen, S.-M.; Chiu, T.-W.; Velusamy, V.; Hall, J.M.; Chen, T.-W.; Ramaraj, S.K. Selective colorimetric detection of nitrite in water using chitosan stabilized gold nanoparticles decorated reduced graphene oxide. Sci. Rep. 2017, 7, 14182. [CrossRef] [PubMed]

26. Kaewtong, C.; Noiseephum, J.; Uppa, Y.; Morakot, N.; Morakot, N.; Wanno, B.; Tuntulani, T.; Pulpoka, B. A reversible $E_{\mathrm{m}}$-fret rhodamine-based chemosensor for carboxylate anions using a ditopic receptor strategy. New J. Chem. 2010, 34, 1104-1108. [CrossRef] 
27. He, G.J.; Zhang, X.L.; He, C.; Zhao, X.W.; Duan, C.Y. Ratiometric fluorescence chemosensors for copper(II) and mercury(II) based on fret systems. Tetrahedron 2010, 66, 9762-9768. [CrossRef]

28. Soh, J.H.; Swamy, K.M.K.; Kim, S.K.; Kim, S.; Lee, S.H.; Yoon, J. Rhodamine urea derivatives as fluorescent chemosensors for $\mathrm{Hg}^{2+}$. Tetrahedron Lett. 2007, 48, 5966-5969. [CrossRef]

29. Lei, Y.L.; Su, Y.Q.; Huo, J.C. Photophysical property of rhodamine-cored poly(amidoamine) dendrimers: Simultaneous effect of spirolactam ring-opening and pet process on sensing trivalent chromium ion. J. Lumin. 2011, 131, 2521-2527. [CrossRef]

30. Sorsak, E.; Valh, J.V.; Urek, S.K.; Lobnik, A. Application of pamam dendrimers in optical sensing. Analyst 2015, 140, 976-989. [CrossRef] [PubMed]

31. Wurth, C.; Grabolle, M.; Pauli, J.; Spieles, M.; Resch-Genger, U. Relative and absolute determination of fluorescence quantum yields of transparent samples. Nat. Protoc. 2013, 8, 1535-1550. [CrossRef] [PubMed]

32. Bhorge, Y.R.; Chou, T.-L.; Chen, Y.-Z.; Yen, Y.-P. New coumarin-based dual chromogenic probe: Naked eye detection of copper and silver ions. Sens. Actuators B Chem. 2015, 220, 1139-1144. [CrossRef]

33. Geddes, C.D. Metal-enhanced fluorescence. Phys. Chem. Chem. Phys. 2013, 15, 19537. [CrossRef] [PubMed]

34. Lobnik, A.; Wolfbeis, O.S. Probing the polarity of sol-gels and ormosils via the absorption of nile red. J. Sol-Gel Sci. Technol. 2001, 20, 303-311. [CrossRef]

35. Xue, Z.W.; Chen, M.L.; Chen, J.M.; Han, J.H.; Han, S.F. A rhodamine-benzimidazole based sensor for selective imaging of acidic pH. RSC Adv. 2014, 4, 374-378. [CrossRef]

36. Fang, Y.; Zhou, Y.; Li, J.-Y.; Rui, Q.-Q.; Yao, C. Naphthalimide-rhodamine based chemosensors for colorimetric and fluorescent sensing $\mathrm{Hg}^{2+}$ through different signaling mechanisms in corresponding solvent systems. Sens. Actuators B Chem. 2015, 215, 350-359. [CrossRef]

37. Lee, S.; Rao, B.A.; Son, Y.-A. A highly selective fluorescent chemosensor for $\mathrm{Hg}^{2+}$ based on a squaraine-bis(rhodamine-b) derivative: Part II. Sens. Actuators B Chem. 2015, 210, 519-532. [CrossRef]

38. Xie, P.H.; Guo, F.Q.; Xia, R.R.; Wang, Y.; Yao, D.H.; Yang, G.Y.; Xie, L.X. A rhodamine-dansyl conjugate as a fret based sensor for $\mathrm{Fe}^{3+}$ in the red spectral region. J. Lumin. 2014, 145, 849-854. [CrossRef]

39. Lobnik, A.; Turel, M.; Urek, S.K.; Kosak, A. Nanostructured materials use in sensors: Their benefits and drawbacks. Carbon Oxide Nanostruct. 2010, 5, 307-354.

40. Oehme, I.; Wolfbeis, O.S. Optical sensors for determination of heavy metal ions. Microchim. Acta 1997, 126, 177-192. [CrossRef]

41. Chhatwal, M.; Kumar, A.; Singh, V.; Gupta, R.D.; Awasthi, S.K. Addressing of multiple-metal ions on a single platform. Coord. Chem. Rev. 2015, 292, 30-55. [CrossRef]

42. Yang, Y.K.; Yook, K.J.; Tae, J. A rhodamine-based fluorescent and colorimetric chemodosimeter for the rapid detection of $\mathrm{Hg}^{2+}$ ions in aqueous media. J. Am. Chem. Soc. 2005, 127, 16760-16761. [CrossRef] [PubMed]

43. Wu, J.S.; Hwang, I.C.; Kim, K.S.; Kim, J.S. Rhodamine-based $\mathrm{Hg}^{2+}$-selective chemodosimeter in aqueous solution: Fluorescent off-on. Org. Lett. 2007, 9, 907-910. [CrossRef] [PubMed]

44. Turel, M.; Duerkop, A.; Yegorova, A.; Karasyov, A.; Scripinets, Y.; Lobnik, A. Microtiterplate phosphate assay based on luminescence quenching of a terbium complex amenable to decay time detection. Anal. Chim. Acta 2010, 675, 42-48. [CrossRef] [PubMed]

45. Saari, L.A.; Seitz, W.R. Ph sensor based on immobilized fluoresceinamine. Anal. Chem. 1982, 54, 821-823. [CrossRef]

46. Jin, Z.; Su, Y.; Duan, Y. An improved optical pH sensor based on polyaniline. Sens. Actuators B Chem. 2000, 71, 118-122. [CrossRef]

(C) 2018 by the authors. Licensee MDPI, Basel, Switzerland. This article is an open access article distributed under the terms and conditions of the Creative Commons Attribution (CC BY) license (http://creativecommons.org/licenses/by/4.0/). 